As-Syifaa Vol 10 (02) : Hal. 152-160, Desember 2018

ISSN : 2085-4714

\title{
UJI AKTIVITAS LARVASIDA PERASAN HERBA SELEDRI (Apium graveolens L.) TERHADAP LARVA Aedes aegypti
}

\author{
Dian Kartikasari, Mentari Novitasari \\ Akademi Farmasi Yarsi Pontianak, Kalimantan Barat \\ Email: diankartikasari223@gmail.com
}

\begin{abstract}
The people of West Kalimantan tend to store water in water reservoirs around their homes, so that the water reservoirs are preferred to be used as breeding sites for Aedes aegypti mosquitoes. Prevention of the development of mosquitoes is very important, one program to suppress mosquito transmission is by eradicating larvae. The many negative effects of synthetic larvicides make the use of cytetic larvicides restricted, thus encouraging the development of natural larvicides, which are safe for the human body, easily accessible and environmentally friendly. Celery is one of the vegetable larvicides that is being developed by several researchers, so the purpose of this study is to determine the larvicidal activity of celery herb infused and to determine the concentration that can kill the most larvae and determine the values of $L C_{50}, L C_{100}$ and $L T_{50}, L T_{100}$. This research was conducted with a concentration of $1 \%, 2 \%, 3 \%, 4 \%$ and $5 \%$, positive control (abate 0.01\%) and negative aquadest control tested on 25 larvae for 24 hours. The results of this study showed the highest Mortality Percentage of mortality of Aedes aegypti larvae obtained from the infused of celery herbs (Apium graveolens L.) at a concentration of 5\% which was $98.64 \%$. Lethal concentration ( $L C_{50}$ ) infused of celery (Apium graveolens $L$.) as larvacide was 1.88\%, LC $1004.43 \%$, and Lethal Time ( $\left.L T_{50}\right)$ at 12.39 hours, $L T_{100}$ at 29.42 hours
\end{abstract}

Key words: Infused, Apium graveolens L., larvicides, Letal Concetration, Letal time.

\section{PENDAHULUAN}

Demam Berdarah Dengue (DBD) adalah penyakit yang disebabkan virus dengue yang merupakan sejenis virus yang masuk ke tubuh manusia melalui gigitan nyamuk Aedes aegypti betina. Di Indonesia sendiri pada tahun 2014 jumlah penderita DBD yang dilaporkan sebanyak 100.347 kasus dengan jumlah kematian sebanyak 907 orang. ${ }^{1}$
Demam Berdarah Dengue (DBD) dapat berakibat fatal dan seringkali menyebabkan kematian.

Penyakit DBD menjadi permasalahan kesehatan masyarakat yang perlu mendapat perhatian serius. Nyamuk Aedes aegypti biasanya berada di lingkungan perumahan yang terdapat banyak genangan air bersih dalam bak mandi atau tempayan. 
Uji aktivitas larvasida perasan herba seledri (시 aegypti

Pengendalian larva nyamuk dapat dilakukan dengan beberapa cara. Salah satunya yaitu secara kimiawi menggunakan bubuk abate. Namun penggunaan larvasida kimiawi secara terus menerus dapat menyebabkan peningkatan resistensi pada larva nyamuk. Selain itu, juga dapat berdampak negatif seperti pencemaran air akibat residu yang tertinggal di penampungan air dan dapat berdampak buruk bagi kesehatan. Oleh karena itu, dampak negatif tersebut harus dikurangi dengan memilih pengendalian secara hayati atau nabati.

Salah satu tanaman yang dapat digunakan sebagai larvasida nabati adalah herba seledri. Herba seledri diketahui mengandung senyawa alkaloid, flavonoid, tanin dan saponin yang dapat bekerja sebagai larvasida. Alkaloid dan saponin merupakan racun perut pada larva. ${ }^{2}$ Flavonoid bekerja mengganggu sistem pernafasan larva dan tanin mempengaruhi kegagalan moulting pada larva sehingga mati sebelum berkembang menjadi pupa. ${ }^{3}$

Herba seledri banyak ditemui di daerah manapun. Herba seledri juga sering digunakan sebagai pemberi aroma atau penyedap rasa pada makanan. Oleh karena itu, timbul pemikiran untuk menggunakan herba seledri sebagai alternatif dalam membasmi larva nyamuk Aedes aegypti. Namun dasar penggunaan tanaman tersebut sebagai larvasida belum banyak diteliti sehingga perlu dilakukan penelitian yang bersifat ilmiah yaitu aktivitas larvasidanya.

Larvasida merupakan golongan dari pestisida yang dapat membunuh serangga belum dewasa atau sebagai pembunuh larva. Larvasida berasal dari bahasa Yunani yang terdiri dari 2 suku kata, yaitu Lar berarti serangga belum dewasa dan Sida berarti pembunuh. Jadi larvasida dapat diartikan sebagai pembunuh serangga yang belum dewasa atau pembunuh ulat (larva). Pemberantasan nyamuk menggunakan larvasida merupakan metode terbaik untuk mencegah penyebaran nyamuk. Parameter aktivitas larvasida suatu senyawa kimia dilihat dari kematian larva. Senyawa bersifat larvasida juga bisa digunakan sebagai sediaan insektisida untuk membasmi serangga yang belum dewasa dan serangga dewasa.

Penggunaan larvasida untuk membunuh larva nyamuk sebelum berkembang menjadi dewasa dapat mengurangi atau menghapus kebutuhan penggunaan pestisida untuk membunuh nyamuk dewasa. ${ }^{4}$ 
Uji aktivitas larvasida perasan herba seledri (시 aegypti

\section{METODE PENELITIAN}

\section{Alat dan Bahan}

Alat yang digunakan dalam penelitian adalah timbangan analitik, saringan, gelas kimia, batang pengaduk, gelas ukur, corong kaca, gelas plastik, kain flannel, gunting dan wadah larva nyamuk. Bahan yang digunakan dalam penelitian yaitu herba seledri (Apium graveolens L.), aquadest, temephos (Abate $\AA)$, larva nyamuk Aedes aegypti.

\section{Pembuatan Larutan Uji Perasan} Herba Seledri

Sebagai larutan uji dibuat larutan stok perasan herba seledri dengan konsentrasi 100\%. Herba seledri ditimbang $100 \mathrm{~g}$ lalu dicuci bersih dengan air mengalir. Setelah itu dirajang dengan maksud mempermudah dalam menghaluskan herba seledri. Herba seledri dihaluskan menggunakan blender dengan menambahkan air 100 mL Kemudian diperas dan disaring menggunakan kain flannel. Setelah larutan stok telah siap, selanjutnya diencerkan dengan konsentrasi $1 \%$, $2 \%, 3 \%, 4 \%$ dan $5 \%$.

\section{Pembuatan Larutan Kontrol Positif}

Larutan kontrol positif dibuat dengan konsentrasi 0,01\% sebanyak 1 liter dengan cara bubuk abate ditimbang $0,1 \mathrm{~g}$ lalu dilarutkan dalam air sebanyak 1 liter.

\section{Penyiapan Sampel Uji}

Sampel uji yang digunakan yaitu larva nyamuk Aedes aegypti yang didapat dari Laboratorium Entomologi Politeknik Kesehatan Kemenkes Pontianak. Jumlah larva yang digunakan adalah 25 ekor per kelompok perlakuan. Terdapat 5 kelompok perlakuan yang terdiri dari kontrol positif, kontrol negatif, perasan $1 \%, 2 \%, 3 \%, 4 \%$ dan $5 \%$ dengan 3 kali replikasi setiap kelompok perlakuan sehingga dibutuhkan sekitar 525 ekor larva.

\section{Uji Aktivitas}

Terdapat 7 kelompok perlakuan. Setiap kelompok berisikan $100 \mathrm{ml}$ larutan dengan konsentrasi berbeda. Kelompok I berisi larutan abate (Kontrol positif), kelompok II berisi aquadest (Kontrol negatif), kelompok III berisi perasan 1\%, kelompok IV berisi perasan $2 \%$, kelompok $\mathrm{V}$ berisi perasan $3 \%$, kelompok VI berisi perasan 4\% dan kelompok VII berisi perasan 5\%. Masukkan masing-masing larutan uji ke dalam gelas plastik. Setelah semua sampel siap, masukkan larva nyamuk ke masing-masing gelas tersebut sebanyak 25 ekor. Lakukan dilakukan pengamatan selama 24 jam dengan 
Uji aktivitas larvasida perasan herba seledri (시 aegypti

pengamatan jam ke-1, 2, 3, 4, 6, 8, 12,

angka

kematiannya

setiap

16, 20 dan 24. Kemudian dicatat

pengamatan. ${ }^{5}$

\section{HASIL PENELITIAN}

Tabel 1. Hasil analisis persen mortalitas kematian pada 24 jam tiap kelompok.

\begin{tabular}{ccccccc}
\hline \multirow{2}{*}{ Kelompok } & \multirow{2}{*}{ Kelompok } & $\begin{array}{c}\text { Mean } \\
\text { Difference }\end{array}$ & $\begin{array}{c}\text { Std. } \\
\text { Error }\end{array}$ & \multirow{2}{*}{ Sig. } & \multicolumn{2}{c}{ 95\% Confidence Interval } \\
\cline { 6 - 7 } & kontrol- & 25.00000 & 1.20844 & .000 & 20.5297 & 29.4703 \\
& perasan 1\% & 17.33333 & 1.20844 & .000 & 12.8631 & 21.8036 \\
\multirow{3}{*}{ kontrol+ } & perasan 2\% & 7.00000 & 1.20844 & .001 & 2.5297 & 11.4703 \\
& perasan 3\% & 5.66667 & 1.20844 & .007 & 1.1964 & 10.1369 \\
& perasan 4\% & 1.33333 & 1.20844 & 1.000 & -3.1369 & 5.8036 \\
& perasan 5\% & .33333 & 1.20844 & 1.000 & -4.1369 & 4.8036 \\
\hline
\end{tabular}

\section{PEMBAHASAN}

Penelitian ini melakukan ekstraksi dengan metode perasan, dimana herba seledri dibuat dalam bentuk perasan karena merupakan cara yang paling sederhana dan sering digunakan oleh masyarakat. Selain itu, bentuk perasan lebih aman dari pada dalam bentuk ekstrak yang menggunakan pelarut kimia tertentu. Konsentrasi perasan yang digunakan yaitu $1 \%$, 2\%, 3\%, 4\% dan 5\%. Dalam penelitian ini, digunakan larva Aedes aegypti instar 3, karena pada stadium ini, larva membutuhkan makanan untuk berkembang sehingga perasan seledri dapat terminum oleh larva. Pada stadium pupa, sudah tidak memerlukan makanan lagi ${ }^{6}$. Larva instar III ukurannya sudah cukup besar sehingga mudah untuk diidentifikasi serta merupakan sampel penelitian yang menjadi standar dari WHO. Larva instar III juga tidak cepat berubah menjadi pupa dan sudah memiliki struktur tubuh yang terbentuk sempurna namun dinding tubuhnya belum mengalami pengerasan. ${ }^{7} \mathrm{WHO}$ dalam Dengue Guidelines for diagnosis, treatment, prevention and control menyatakan bahwa jumlah larva yang digunakan dalam penelitian adalah sebanyak 25 ekor larva. Selain itu, dari segi teknis media yang digunakan adalah gelas yang berisi air $100 \mathrm{~mL}$, apabila media diisi lebih dari 25 ekor, kematian larva bisa karena faktor kepadatan dalam media. ${ }^{7}$

Kontrol positif yang digunakan adalah larutan abate (Themepos) 0,01\%. Kontrol positif dimaksudkan untuk melihat dan membandingkan keefektifan larvasida alami dalam membunuh larva uji. Kontrol negatif 
Uji aktivitas larvasida perasan herba seledri (시 aegypti

yang digunakan yaitu aquadest.

Penelitian dilakukan dalam 3 kali replikasi atau pengulangan dengan tujuan untuk meminimalisir kesalahan, selain itu untuk mengurangi bias dalam penelitan sehingga hasil penelitian benar-benar valid. ${ }^{7}$ Dari hasil pengamatan terlihat pada kontrol negatif tidak ada yang mengalami
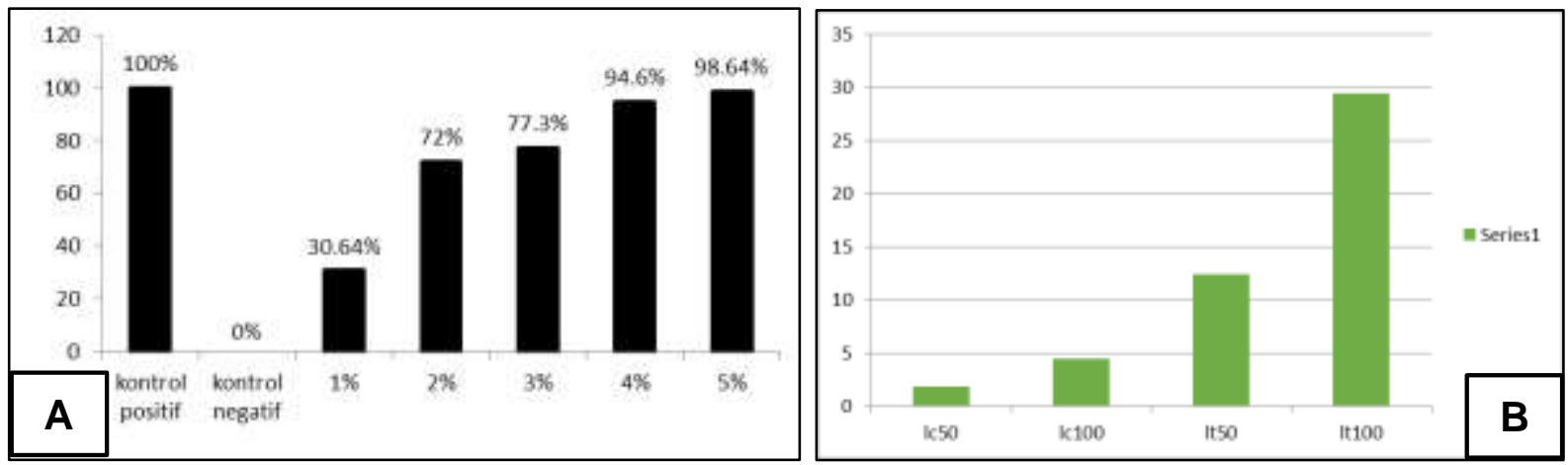

kematian. Hal ini menunjukkan aquadest tidak memberikan efek membunuh larva nyamuk dan suhu ruangan yang digunakan tidak mempengaruhi larva nyamuk. Hasil pengamatan persen mortalitas larva nyamuk pada 24 jam dapat dilihat dan gambar $1(\mathrm{~A})$.

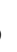

Gambar 1. (A) Pengamatan 24 jam persen mortalitas larva Aedes aegypti; (B) Nilai Lhetal Concentration dan Lhetal Time.

Gambar 1 (A) menunjukkan jumlah dan presentase kematian larva Aedes aegypti setelah 24 jam. Pada konsentrasi terendah yaitu $1 \%$ saja sudah dapat membunuh larva sebesar $30,64 \%$ dan pada konsentrasi tertinggi yaitu $5 \%$ sudah membunuh $98,64 \%$ larva. Artinya, perasan herba seledri terbukti dapat berkhasiat sebagai larvasida alami. Semakin tinggi konsentrasi yang diberikan maka semakin besar persentase kematian larva. Pada kontrol positif kematian sebesar $100 \%$, abate yang merupakan kontrol positif bersifat anti

kolinesterase yang bekerja dengan mengikat enzim kolinesterase sehingga menimbulkan terjadinya kontraksi otot terus menerus yang menyebabkan kematian larva. ${ }^{8}$ Sedangkan pada kontrol negatif tidak terdapat kematian larva. Hal ini menunjukkan bahwa aquadest tidak mampu membunuh larva karena larva Aedes aegypti dapat hidup di air bersih. Nilai persen mortalitas kematian larva pada 24 jam selanjutnya dianalisis dengan Anova one Way. Hasil analisis dapat dilihat pada tabel 1. 
Uji aktivitas larvasida perasan herba seledri (시 aegypti

Tabel 1 menunjukkan perasan $4 \%$ dan perasan $5 \%$ memiliki efektifitas yang sama dengan kontrol positif. Dimana pada tabel 1 ditunjukkan nilai signifikansinya yaitu 1,00. Berdasarkan cara masuk larvasida dalam hal ini perasan seledri ke dalam tubuh larva Aedes aegypti dapat dinyatakan sebagai racun kontak dan racun pernafasan. Sebagai racun kontak, perasan seledri dapat langsung mengenai bagian tubuh larva yang menyebabkan kematian yang ditandai dengan tubuh larva diam dan tidak mampu menyentuh permukaan. perasan seledri dinyatakan sebagai racun kontak apabila dapat masuk kedalam tubuh larva nyamuk lewat kulit bersinggungan langsung. ${ }^{9}$ Selain itu dapat dilihat bahwa jumlah kematian larva berbeda pada setiap konsentrasi yang diberikan.

Berdasarkan hasil penelitian menunjukkan bahwa konsentrasi minimal tiap ekstrak tumbuhan memberikan perbedaan daya bunuh terhadap larva Aedes aegypti, hal ini disebabkan jumlah bahan aktif yang ada di dalam ekstrak, pada Daun Zodia (Euvodia graveolens), konsentrasi minimal 1,56 \% mampu membunuh larva 100\% dengan bahan aktif dominan evodiamine. Daun Tembakau (Nicotiana tabacum) konsentrasi minimal $1,56 \%$ mampu membunuh larva 100\% dengan bahan aktif dominan alkaloid. Serai wangi/rimpang (Andropogon nardus), konsentrasi minimal $1,56 \%$ mampu membunuh larva $68,0 \%$ dengan bahan aktif dominan asam vetivetate. Lengkuas/rimpang (Alpinia galanga) konsentrasi minimal 1,56 \% mampu membunuh larva 29,3\% dengan bahan aktif dominan flavonoid. Daun Rosemary (Rosmarinus officinalis L.) konsentrasi minimal 1,56 \% mampu membunuh larva $78,7 \%$ dengan bahan aktif dominan alkaloid. ${ }^{10}$

Berdasarkan hasil skrinning fitokimia yang dilakukan ${ }^{11}$ herba seledri mengandung alkaloid, flavonoid, tannin dan saponin. Semua senyawa tersebut diduga memiliki aktivitas sebagai larvasida. Alkaloid mampu menghambat pertumbuhan serangga (larva), terutama tiga hormon utama dalam serangga yaitu hormon otak, hormon edikson dan hormon pertumbuhan. Tidak berkembangnya hormon tersebut dapat menyebabkan kegagalan metamorphosis. Alkaloid juga dapat mendegradasi membran sel untuk masuk ke dalam dan merusak sel serta dapat juga mengganggu sistem kerja syaraf larva dengan menghambat kerja enzim 
Uji aktivitas larvasida perasan herba seledri (시 aegypti

asetilkolinesterase yang akan

permukaan tubuh larva dan mengganggu transmisi rangsang sehingga terjadi penurunan koordinasi otot dan menyebabkan kematian. ${ }^{12}$ Senyawa alkaloid juga menyebabkan terjadinya perubahan warna pada tubuh larva menjadi lebih transparan dan gerakan tubuh larva yang melambat bila dirangsang sentuhan serta selalu membengkokkan badan. ${ }^{13}$ Hal itu ditunjukkan pada perlakuan kontrol negatif, larva berwarna coklat dan bergerak aktif. Sedangkan pada larva yang telah diberi perlakuan perasan herba seledri, tubuh larva menjadi lebih transparan dan bergerak kurang aktif.

Saponin berperan sebagai penghambat makan pada serangga

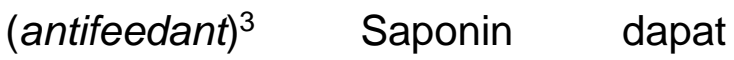
menunrunkan tegangan permukaan selaput mukosa saluran pencernaan larva sehingga dinding saluran pencernaan menjadi korosif. Bila senyawa tersebut masuk dalam tubuh larva Aedes aegypti maka alat pencernaannya akan terganggu. ${ }^{2}$ Selain itu, saponin akan mengganggu perkembangan dan gangguan pergantian kulit pada larva (moulting) sehingga larva tidak akan mampu berkembang ke stadium selanjutnya. Flavonoid bekerja dengan menyerang sistem pernafasan yang ada pada menimbulkan kelayuan syaraf sehingga tidak mampu bernafas. ${ }^{14}$ Tannin dapat mempengaruhi kegagalan moulting pada larva sehingga mati sebelum berkembang menjadi pupa. ${ }^{3}$ Selanjutnya dilakukan perhitungan nilai Lethal Concentration (LC) dan Lhetal Time (LT).

Gambar 1 (B), memperlihatkan konsentrasi kematian untuk 50\% dan $100 \%$ dari jumlah sampel, pada larva instar 3. Berdasarkan grafik 2, didapatkan nilai $\mathrm{LC}_{50}$ adalah $1,88 \%$. Itu artinya untuk membunuh 50\% larva instar 3 dibutuhkan perasan seledri dengan konsentrasi $1,88 \%$. Nilai LC $_{100}$ yaitu 4,42\%. Itu artinya untuk membunuh 100\% larva instar 3 dibutuhkan perasan seledri dengan konsentrasi $4,42 \%$. Semakin rendah nilai $\mathrm{LC}_{50}$ dan $\mathrm{LC}_{100}$ semakin baik, karena dengan konsentrasi kecil sudah dapat membunuh populasi, sehingga efektivitas penggunaan bahan baku tercapai.

Gambar 1

(B) juga memperlihatkan waktu kematian untuk $50 \%$ dan $100 \%$ dari jumlah sampel, pada larva instar 3. Nilai LT50 pada instar 3 yaitu 12,40 jam, artinya pada 12,40 jam waktu yang dibutuhkan untuk dapat membunuh 50\% populasi instar 3. Sementara LT100 pada instar 3 
Uji aktivitas larvasida perasan herba seledri (시 aegypti

yaitu 29,42 jam, artinya dibutuhkan waktu 29,42 jam untuk dapat membunuh $100 \%$ populasi larva instar 3. Semakin kecil nilai $L T_{50}$ dan $L T_{100,}$ artinya semakin baik sehingga waktu yang diperlukan untuk membunuh larva nyamuk Aedes aegypti semakin cepat, sehingga efisiensi waktu tercapai.

\section{KESIMPULAN}

Perasan herba seledri pada konsentrasi $4 \%$ dan 5\% memiliki efektifitas yang sama dengan kontrol positif (abate). Nilai $\mathrm{LC}_{50}$ adalah 1,88\%, LC 100 yaitu $4,42 \%$, dan $\mathrm{LT}_{50}$ yaitu 12,40 jam, LT 100 yaitu 29,42 jam.

\section{DAFTAR PUSTAKA}

1. Kemenkes RI. Profil Kesehatan Indonesia $2014 . \quad$ Jakarta: Kementrian Kesehatan Republik Indonesia, 2015.

2. Hayani, Eni \& Fatimah, Tjitjah. Identifikasi Komponen Kimia dalam Biji Mengkudu (Morinda citrifolia). Prosiding Temu Teknis Nasional Tenaga Fungsional Pertanian Tahun 2004, 2004.

3. Asikin S. Toksisitas Tumbuhan Jengkol Terhadap Hama Tanaman. Banjarbaru: Badan Penelitian Pertanian Lahan Rawa, 2013.

4. Aradilla, Ashry S. Uji Aktivitas Larvasida Ekstrak Ethanol Daun Mimba (Azadirachta indica) Terhadap Larva Aedes aegypti (Skripsi). Semarang: Fakultas Kedokteran Universitas Diponegoro, 2009.
5. Surahman, Mochamad R, Sudibyo S. Metodologi Penelitian Farmasi. Jakarta: Pusat Pengembangan SDM, Kementrian Kesehatan Republik Indonesia, 2016.

6. Depkes RI. Aedes aegypti Vampir Mini yang Mematikan. Jakarta: Badan Penelitian dan Pengembangan Kesehatan Depkes RI, 2007.

7. Nurhaifah, Dita \& Tri Wahyuni S. Efektivitas Air Perasan Kulit JEruk Manis sebagai Larvasida Nyamuk Aedes aegypti. Jurnal Kesehatan Masyarakat Nasional. 2015;9(3): 209.

8. Ridha MR, Nisa K. Larva Aedes Aegypti sudah Toleran Terhadap Temepos di Kota Banjarbaru, Kalimantan Selatan. Jurnal Vektora. 2011; 3(2).

9. Djojosumarto P. Teknik Aplikasi Pestisida Pertanian. Yogyakarta: Kanisius, 2000.

10. Hasan B, Bambang H, Sri WH, Tri S. Uji Toksisitas Beberapa Ekstrak Tanaman Terhadap Larva Aedes aegypti Vektor Demam Berdarah Dengue. Jurnal Vektora. 2015; 7 (1):29-38.

11. Putra, Hexy TP. Formulasi dan Uji Efektivitas Sediaan Emulsi Perangsang Pertumbuhan Rambut Ekstrak Seledri (Apium graveolens Linn.) (Skripsi). Bogor: Universitas Pakuan, 2013.

12. Robinson. Kandungan Organik Tumbuhan Tinggi. Edisi IV. Bandung: ITB, 1995.

13. Cania ES. Uji Efektivitas Larvasida Ekstrak Daun Legundi (Vitex 
Uji aktivitas larvasida perasan herba seledri (Apium graveolens L.) terhadap larva Aedes aegypti

trifolia) Terhadap Larva Aedes Aegypti. Majorit.2013;2(4):52-60.

14. Oluremi OI, Ngi J, Andrew IA. Phytonutrients in citrus fruit peel meal and nutritional implication [serial on internet]. Livestock Research for Rural Development. 2007;19(7). Retrieved August 27, 2018, from http://www.Irrd.org//rrd19/7/olur190 89.htm. 